\title{
Developing Innovative Services: The Case of the Airport Environment
}

\author{
Sofia Gkika, Katerina Fraidaki, and Katerina Pramatari \\ Department of Management Science and Technology, \\ Athens University of Economics and Business, \\ 47a Evelpidon and 33 Lefkados str, Athens, 113 62, Greece \\ \{gkikas,fraidaki,k.pramatari\}@aueb.gr
}

\begin{abstract}
Innovative services consist the main point of interest so for academics as for the business world. The basic objective of this paper is to demonstrate the way that innovative services may change the "consumer experience" in the airport environment. In the following lines we describe the procedure of designing innovative services, so for consumers' and visitors' needs as for the needs of the firms which are operated in the airport environment. In order to achieve this goal, we used so the qualitative approach (such as focus groups), as the quantitative approach (collection of 1106 questionnaires).
\end{abstract}

Keywords: electronic services, innovation, business models.

\section{Introduction}

Roger's (1998) defines innovation as “... the process of introducing new ideas to the firm which result in increased firm performance”. Schumpter (1983) confirms the existence of five types of innovation: (1) introduction of new product or the change of the existed one, (2) process innovation, (3) opening of a new market, (4) development of new sources of supply of raw materials and (5) changes in the industrial organization.

Innovation has become the key marketers' tool, in order to ameliorate customers' experience. Being focused on the airport environment, customers are divided into four categories: visitors, travellers, firms and firms' employees. Our basic objective is to design innovative services which will direct in these different groups, taking into consideration their special needs.

The following paper is focused on the first type of innovation; to be more specific we are going to "change the way that existing services operate". The purpose of our study is to be emerged sservices for the case study of a Greek airport. The target groups of these services are on the one hand the visitors and the consumers of the airport and on the other hand the firms and their employees that are activated in the specific environment. We aim to design services which will be bought by the firms in order to be given to their customers while they are situated in the airport. The services will be delivered to the final customer via a platform named CAP-Common Airport Platform. This platform will be managed by the managers of the airport; so the firms as the customers will have access using a specific code. The services that we introduce are: Discount Coupons, Traffic Map, Last Minute Tickets and Time2Gate. 
The following paper is divided in four sections. Section One describes the existent services in the specific context and analyses the methodology of our survey. Section Two describes the methodology that was followed in our research, the related work, the focus groups that revealed and described how the survey was conducted. Section Three analyses the services which will be developed, as well as the proposed business model of each service. Finally, section Four contains a brief discussion.

\section{Methodology}

In order to design the innovative services, we started our research with exploration of our "customers" (visitors, travelers, firms and firms' employees) needs. In order to achieve this goal, we used to the method of focus groups, as the one of the survey. Finally, we designed the services, describing their full business model.

\subsection{Related Work}

The first step of our research was the analysis of the context in which we wanted to design the innovative services. Studying the permanent literature we tried to identify the services which have been offered until now, by the airports. Table 1 mentions the basic services. As we may notice they are separated in two categories: services towards firms (B2B Services) and services towards passengers (B2C Services).

Table 1. Existing services

\begin{tabular}{|l|l|}
\hline B2B Services & Voice Communication Services \\
\cline { 2 - 3 } & TETRA Digital Radio Ground to Ground Communication \\
\cline { 2 - 3 } & IT\&T Support Services \\
\hline & Flight Information Display Service \\
\hline & Data Communication \& Internet Services \\
\cline { 2 - 3 } & Cabling Services \\
\hline & Data Centre Services \& IT Operations \\
\hline & $\begin{array}{l}\text { Added Value Consulting Services to other Airports and } \\
\text { Transportation Operators }\end{array}$ \\
\hline & Wireless Access \\
\hline & Common Use Terminal Equipment (CUTE) \\
\cline { 2 - 3 } & Common Use Self Service kiosks (CUSS) \\
\hline Passenger services & Business Center Services \\
\cline { 2 - 2 } & Internet kiosks \\
\cline { 2 - 2 } & Card phones \\
\cline { 2 - 2 } & Wi-Fi (wireless) Internet access \\
\hline
\end{tabular}

The basic characteristic of this context is the limited time that a passenger/visitor consumes while (s)he visits an airport. Normally, either heavy passengers (people who travel once every three months of more often) or light passengers consume one and half hours in the airport, before they travel; on the other hand airport offers sixty (60) minutes of free Internet in order to fulfil his/her needs. 


\subsection{Focus Groups}

Bruseberg (2001) confirms that the most useful way to understand peoples' needs is focus groups. Having studied the existed services, the next steps are on the one hand the investigation of the needs that our target group wants to fulfil the most; and on the other hand the investigation of services that could be considered as innovative. For this reason we conducted five focus groups: two of them consist of managers and employees of the firms and the other three of consumers. Every focus group was consisted of 6 people. In order to choose the members of the groups we used Matthing's questionnaire (2006) (Appendix). Matthing proved that being based on how innovative a person can be considered, we may recognise five types of people (starting from the most innovative to the less one): leaders/ explorers, pioneers, sceptics, paranoids and laggards. The questionnaire was distributed in 59 people of the airport community. We chose 30 people and in every group there was at least one leader/ explorer and no paranoids and laggards.

Having analysed the data of the qualitative approach we identified 40 innovative services (33 services towards passengers/ visitors, 5 services towards firms and 2 services towards the employees of the airport). The services could be categorised into three categories: informational, transactional and hedonic/social services. Their basic characteristic is that they refer either to the advanced version of existing services or to the design of completely new services.

\subsection{Survey}

In order to evaluate the previous services, we used the quantitative approach, conducting a survey in the airport environment. Because of the limited space of the questionnaire we chose three services from every category. The basic objective of this survey was to understand the attitude towards the services. We measured this construct using a two item scale (very interesting/ not interesting at all and very useful/ not useful at all). At the same time we tried to investigate the basic characteristics of the passengers which will help us to design the Business Models of every service.

We collected 1106 answers. The descriptive characteristics of the sample are: 60\% of the people who answered the questionnaire are between $18-35$ years old, $51 \%$ were female and 30\% travel once every six months. Furthermore 50\% uses smart phone during his/her visit in the airport and $57 \%$ of them uses his/her smart phone in order to obtain new services.

Taking into consideration the above analysis as well as the available technology we will develop the following services: discount coupons, traffic map, last minute tickets, time2gate. In the following sections we will fully describe the services and their proposed business model.

\section{Services}

The services will be offered to "consumers", firms and employees via the platform CAP; its main objective is to collect all the services and provide to users a more "user friendly" environment. 


\subsection{Discount Coupons}

In the context of the service "Discount Coupons" (Table 2) firms operating inside the airport and at the airport's park, import into CAP's platform offers in order to inform

Table 2. Discount Coupons

\begin{tabular}{|c|c|}
\hline Components & Description \\
\hline Value Proposition & $\begin{array}{l}\text { Automated provision of offers (for purchases at businesses inside and } \\
\text { outside the space of Airport) through electronic means. }\end{array}$ \\
\hline Customer Segments & $\begin{array}{ll}\text { - } & \text { Registered and non- registered passengers } \\
\text { - } & \text { Registered and non- registered visitors } \\
\text { - } & \text { Airport's staff } \\
\text { - } & \text { Business at airport's area }\end{array}$ \\
\hline Channels & $\begin{array}{l}\text { The electronic proof of the offer will be provided and / or printed by users } \\
\text { through the platform of the Airport, which is accessible via (digital } \\
\text { channels): } \\
\text { - Smart phones \& laptops users } \\
\text { - } \quad \text { desktops and laptops in kiosks in the Airport } \\
\text { - The of Airport } \\
\text { - Displays (FIDS, IPTV and CAP dedicated) } \\
\text { The offers that are not required to be printed / electronic evidence, the bids } \\
\text { will be communicated via display screens of offers via sms to mobile users } \\
\text { or e-mail (digital channel). } \\
\text { Eventually, users will enjoy the offer made in the shops of cooperating firms } \\
\text { in the wider area of the airport (physical channel, indirect collaborative). } \\
\text { The electronic proof of the offer will be provided and / or printed by users } \\
\text { through the platform of the airport, which is accessible via (digital } \\
\text { channels): } \\
\text { - Smart phones \& laptops users } \\
\text { - Desktops and laptops in kiosks in the Airport } \\
\text { - The website of the CAP } \\
\text { - The of Airport } \\
\text { For offers that do not require printed / electronic evidence, the bids will be } \\
\text { communicated via display screens of offers via sms to mobile users or e- } \\
\text { mail (digital channel). } \\
\text { Eventually, users will enjoy the offer made in the shops of cooperating firms } \\
\text { in the wider area of the airport (physical channel, indirect collaborative). }\end{array}$ \\
\hline Customer Relationships & 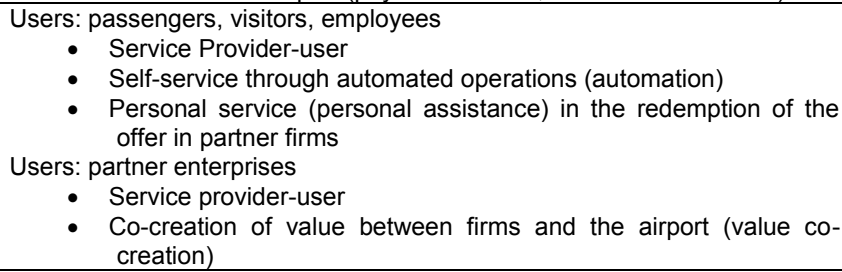 \\
\hline Key Resources & $\begin{array}{l}\text { Physical resources: e.g. computers, network infrastructure, printers } \\
\text { Intellectual resources: e.g. knowledge about the operation of the service, } \\
\text { CMS, algorithms for recommendation systems, etc. } \\
\text { Human resources: e.g. staff }\end{array}$ \\
\hline
\end{tabular}


Table 2. (continued)

\begin{tabular}{|c|c|}
\hline & Financial resources: revenues from 'Discount Coupons' \\
\hline Key Activities & $\begin{array}{l}\text { - Planning offers (business plan of the partner firms) } \\
\text { - } \text { Prodtracts with affiliated firms } \\
\text { supply available (better recommendations), import supply } \\
\text { - } \text { Maintenance Services } \\
\text { - Production and maintenance of platform disposal services } \\
\text { - Production and maintenance of network infrastructure } \\
\text { - } \text { Approval of an offer } \\
\text { Service planning }\end{array}$ \\
\hline Competitive Advantage & $\begin{array}{l}\text { - Personalized offers (leadership \& innovation) } \\
\text { - } \quad \text { Pirport's brand name } \\
\text { - } \quad \text { Compision of electronic coupon } \\
\text { - } \quad \text { Prorge for dynamic updue for money) } \\
\end{array}$ \\
\hline Key Partners & Airport - Business \\
\hline Revenue Streams & 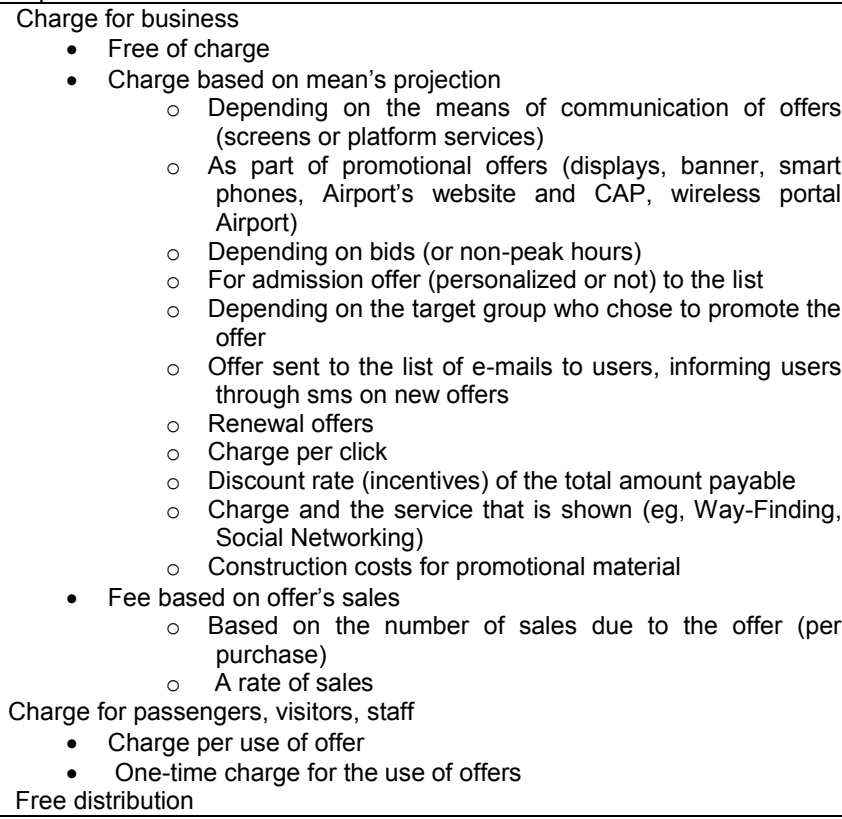 \\
\hline Cost Structure & $\begin{array}{l}\text { - } \quad \text { Purchase of hardware and software } \\
\text { - } \\
\text { - Saintenance of hardware and software } \\
\text { - } \quad \text { Cost of ownership messages } \\
\text { - Fixed monthly operating costs }\end{array}$ \\
\hline
\end{tabular}

the public that have access to the platform through available technological resources (Wi-Fi, SMS, 3G, Airport Campus LAN, etc.). The offers will be provided on a list. Recipients of this service will be all employees, passengers, visitors of the airport as well as residents of neighbouring municipalities. The service will be available through CAP's available communication channels and different types of devices such as laptop, smart phone or tablet PC within the airport or users with Internet access (to region around the airport). Moreover, "Discount Coupons" will be available even 
to people who do not use or do not have any technological means, through the promotion of the offers on monitors located in areas of increased traffic like staff's restaurants or Metropolitan EXPO during an exposure.

The offers that will be provided through CAP will be inserted from the firms. The system can be accessed quickly and easily by any employee of the firm, if (s)he knows the offer's characteristics, the means the offers will project, the time of display, etc. This process is automated so that no special skills or computer knowledge is required.

The actors that act in the service "Discount Coupons" will be the authorized firm's employee that will insert the offer to the Platform; will select the means that the offer will be provided, will check the cost and send the offer to the airport's employee for approval. Subsequently, the airport's authorized employee will be informed about the offer and its cost then will decide whether (s)he will approve or reject it. If (s)he will approve it, offer will be activated, by enabling the provided means. Otherwise, (s)he will inform the airline for the reasons of rejection. The users will be informed for the offer through the means that the firm selected to provide them. In the case of coupons, they download them to their personal devise the coupon's barcode and show it to the cashier while they are paying. The cashier scans the barcode and sends it to the list with the used coupons.

The most important element of the offers' display is personalization. This will be done according to the profile's data that a user entered while registered and / or according to his/her personal history based on the earliest use of coupons. This approach involves registered users and staff of the airport. For non-registered users, the offer proposals will provide personalized via the service "Time2Gate". In this service, the personalized offers depend on the "route" the user seems to follow to the gate of his flight, providing the offers from shops that seem to pass in order to benefit from them and other criteria.

The characteristics that combine the competitive advantage of this service is not only the personalized offers according to user's needs but also the brand of the airport, which gives greater glory to the service. Also, dynamic pricing for the renewal of the list with the offers and coupons, depends on list's amount of visitors when the firm wishes to make the renewal. One more characteristic is the provision of special cost packages for an offer that meet business needs. Moreover, even if there are other services providing this kind of service the advantage of this one is the fact that the user when works or visits the airport has a particular mood which is connected with the airport's environment, so if (s)he knows about this service (s)he will prefer this one.

\subsection{Traffic Map}

This service "Traffic Map" (Table 3) will also be available through the CAP, and it will give users the opportunity to learn about the traffic to and from the airport. Focus groups revealed that it is a very important service, which is very high at passengers' preferences, since information about traffic offers great convenience to anyone that is interested on accessing the airport grounds. This service refers to everyone who wants to go to the airport or leave from the airport. The user can be informed for the alternative access routes to the airport, the total time required for each route and the traffic along the route. The data of the route provided by the National Police 
Table 3. Traffic Map

\begin{tabular}{|c|c|}
\hline Components & Description \\
\hline Value Proposition & $\begin{array}{l}\text { Estimation of the transit time to/from the airport via the default route and } \\
\text { information on whether there are any incidents along the way. Moreover, } \\
\text { users may choose to be provided personalized itineraries according to } \\
\text { their needs and only registered users have the option to save the route. }\end{array}$ \\
\hline Customer Segments & $\begin{array}{ll}\text { - } & \text { Registered and non- registered passengers } \\
\text { - } & \text { Registered and non- registered visitors } \\
\text { - } & \text { Airlines } \\
\end{array}$ \\
\hline Channels & $\begin{array}{l}\text { The service will be accessible via (digital channels): } \\
\text { - Smart phones, laptops and users of Tablet PC, } \\
\text { - CAP's website } \\
\text { - Airport's website and } \\
\text { IPTV monitors }\end{array}$ \\
\hline Customer Relationships & $\begin{array}{l}\text { Users: passengers, visitors, employees } \\
\qquad \quad \text { provider-user } \\
\text { • } \\
\text { self-service through automated operations (automation) }\end{array}$ \\
\hline Key Resources & $\begin{array}{l}\text { Physical resources: e.g. computers, network infrastructure } \\
\text { Intellectual resources: e.g. the brand of the AIRPORT, the required } \\
\text { knowledge, data, algorithms assessment years, the software that } \\
\text { implements the service } \\
\text { Human resources: e.g. staff } \\
\text { Financial resources: the use of service }\end{array}$ \\
\hline Key Activities & $\begin{array}{l}\text { - Production: design, implementation and launch of the service } \\
\text { - Maintenance Services } \\
\text { - Ability to personalize, save routes, notification } \\
\text { - Pramic Update } \\
\text { - Production and maintenance of platform's disposal services } \\
\text { - Calculation of maintenance of network infrastructure } \\
\text { - Update on events affecting the route. }\end{array}$ \\
\hline Competitive Advantage & $\begin{array}{l}\text { - } \quad \text { Airport's brand name } \\
\text { - } \quad \text { Aynamic information about the events that affects the way } \\
\text { - } \quad \text { Ability for customization and / or storage paths } \\
\end{array}$ \\
\hline Key Partners & Airport- Provider (real time data) \\
\hline Revenue Streams & $\begin{array}{l}\text { Charge for passengers, visitors } \\
\text { - Free distribution } \\
\text { - One-time charge for the use of the service } \\
\text { Charge for airlines } \\
\text { - Free distribution } \\
\text { - Single charging for the use of the service } \\
\text { Charge for businesses } \\
\text { - View offers by service 'Discount Coupons' }\end{array}$ \\
\hline Cost Structure & $\begin{array}{ll}\text { - } & \text { Hardware and Software equipment } \\
\text { - } & \text { Maintenance of Hardware and Software } \\
\text { - } & \text { Human resources' salaries } \\
\end{array}$ \\
\hline
\end{tabular}

(Local Traffic Department), according to the press issued by traffic and other sources that can provide that kind of information.

The user selects the starting point, the means of transportation to the airport and the estimated time is calculated automatically. Then, the path shown on the chart and is 
updated for any traffic incidents. If the user is registered, is given the option to save the above route.

The user is able to estimate the required time to go to the airport through default routes. Additionally, there is the possibility of providing personalized itineraries depending on user needs. For example, routes are customized to user needs in order to select either the fastest route or a route with sightseeing. Finally, only the registered users can save the route they chose or receive sms if there is a change in the time that they had originally assumed, because of a potential accident.

The characteristics that build the competitive advantage of the service "Traffic Map" is that the estimated time that displayed to users is based on real information about any potential problems on the route to the airport. Also, it may personalize and / or store routes that a user chose and gives the opportunity for notice and dynamic update of users.

\subsection{Last Minute Tickets}

The aim of this service is to provide cheap air tickets for flights departing the next one to four hours (Table 4). The service will be available to everyone who uses the CAP which is separated in two different levels depending on whether the user is registered or not. In the process of registering a new user can choose if (s)he wants to receive information for promotions on the service either via SMS or via e-mail. Registered users will have the privilege to be informed through SMS or e-mail, one or two hours before the non-registered users in order to keep them on a priority over other users. Because of the fact that the registered users have the privilege of being informed before non-register users, they may be located outside the airport before receiving the information and go to the airport only if (s)he is interested in it. It should be mentioned that the tickets will be "aller-retour".

The actors of the service "Last Minute Tickets" are the authorized airline's employee that insert the offer to the platform, select the means that the offer will be provided, check the cost and send the offer to the airport's employee for approval. Subsequently, the airport's authorized employee informed about the offer and the cost then decides whether to approve or reject it. If (s)he approves it, the offer is activated through the enable of the means that was decided to be projected. Otherwise, (s)he informs the airline for the reasons of rejection. Finally, the users, if they are registered, they are informed earlier than the non-registered user through an sms or an e-mail, or from the airports displays and moves to the airline's desks in order to purchase the ticket.

The most important element of this service is the presence of innovation, as there is no similar service, at least in national data, providing cheaper tickets to users. The user's access to information and booking tickets will be easy and the process will be completed quickly.

The tickets that will be provided through CAP will be inserted from the airlines. This can be done quickly and easily from any employee of the firm, if (s)he knows the login information to the platform, the number of tickets that will be provided, the projection part of tickets, time of display, etc. This process is automated so that not requires any special skills and computer knowledge / technology to use. 
Table 4. Last Minute Tickets

\begin{tabular}{|c|c|}
\hline Components & Description \\
\hline Value Proposition & $\begin{array}{l}\text { Automated allocation of financial tickets (aller-retour), for flights departing in } \\
1-4 \text { hours from the time the offer will be displayed on the electronic means. }\end{array}$ \\
\hline Customer Segments & $\begin{array}{ll}\text { - } & \text { Registered and non- registered passengers } \\
\text { - } & \text { Registered and non- registered visitors } \\
\text { - } & \text { Airlines partners } \\
\text { - } & \text { Airport's staff }\end{array}$ \\
\hline Channels & $\begin{array}{l}\text { Notification for registered users through sms (digital channel). Users are } \\
\text { informed through the platform, which is accessible via (digital channels): } \\
\text { - Smart phones, Laptops \& Tablet PC } \\
\text { - Desktops, Laptops \& Tablet PC's at kiosks within the Airport } \\
\text { Automatic import and tickets' renewal from airlines through the platform of } \\
\text { the Airport (digital channel). } \\
\text { Eventually, people will buy tickets directly from the airlines' desk (physical } \\
\text { channel, indirect collaborative). }\end{array}$ \\
\hline Customer Relationships & $\begin{array}{l}\text { Users: airlines } \\
\text { - Service provider-user } \\
\text { - Co-create value between airlines and Airport (value co-creation) } \\
\text { Users: passengers, visitors, employees } \\
\text { - Service provider-user } \\
\text { - Self (self-service) through automated operations (automation). } \\
\text { Personal service when buying tickets on airlines (personal } \\
\text { assistance) }\end{array}$ \\
\hline Key Resources & $\begin{array}{l}\text { Physical resources: e.g. computers, network infrastructure equipment for } \\
\text { the disposal of the service through transmission service } \\
\text { Intellectual resources: e.g. knowledge about the operation of the service, } \\
\text { databases, software, algorithms } \\
\text { Human resources: e.g. staff } \\
\text { Financial resources: revenues from 'Discount Coupons' }\end{array}$ \\
\hline Key Activities & $\begin{array}{l}\text { - } \quad \text { Design for provided offers (business plan of the partner airlines) } \\
\text { - } \quad \text { Pontracts with the partner airlines } \\
\text { - } \quad \text { Maintenance sesign, implementation, service delivery. } \\
\text { - Production and maintenance of platform disposal services. } \\
\text { - Production and maintenance of network infrastructure. }\end{array}$ \\
\hline Competitive Advantage & $\begin{array}{l}\text { - Personal electronic notice to registered users (leadership \& innovation) } \\
\text { - } \quad \text { Information through digital channels for all users } \\
\text { - } \quad \text { Competititive cost (value for money) } \\
\text { - } \quad \text { Pynamic renewal of fee list } \\
\text { Provision of preferential packages }\end{array}$ \\
\hline Key Partners & Airport - Airlines \\
\hline Revenue Streams & $\begin{array}{l}\text { Charge for business } \\
\text { - Free of charge } \\
\text { Charge based on mean's projection } \\
\circ \text { Depending on the means of communication of offers } \\
\text { (screens or platform services) } \\
\circ \text { As part of promotional offers (displays, banner, smart } \\
\text { phones, Airport's website and CAP, wireless portal } \\
\text { Airport) } \\
\circ \text { Depending on bids (or non-peak hours) } \\
\circ \text { For admission offer (personalized or not) to the list } \\
\circ \text { Depending on the target group who chose to promote the } \\
\text { offer }\end{array}$ \\
\hline
\end{tabular}


Table 4. (continued)

\begin{tabular}{|c|c|}
\hline & 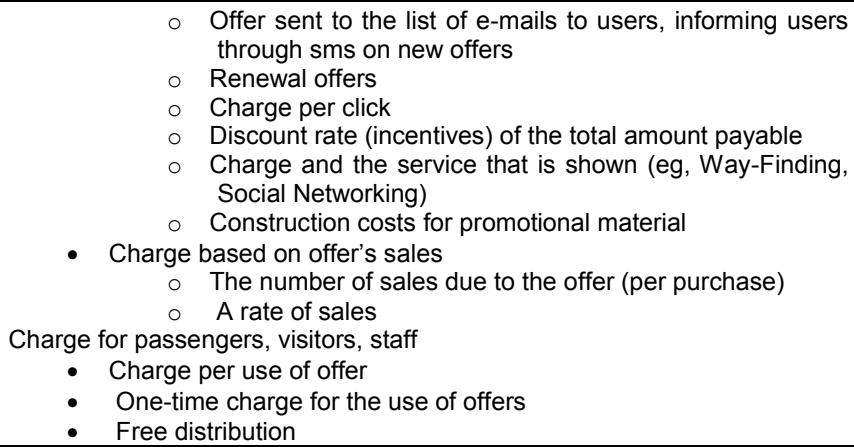 \\
\hline Cost Structure & $\begin{array}{l}\text { - } \text { Purchase of Hardware and Software } \\
\text { - } \text { Maintenance of Hardware and Software } \\
\text { - Staff's salaries } \\
\text { - Cost of ownership messages } \\
\text { - Fixed monthly operating costs }\end{array}$ \\
\hline
\end{tabular}

The components that create competitive advantages that are met in this service is that the service is innovative and all, potentially, customers will wish to know and to use it even once. All processes are automated and no effort is required for the use of this service. Last but not least, the competitive costs (value for money), makes it even more attractive service to customers.

\subsection{Time2Gate}

This service will have as main purpose to provide dynamically information to user (passenger) for the estimated time to go to the terminal gate and is addressed to all CAP's users (Table 5). It should be mentioned, that this is the only service that is applied under the condition that the user is in the airport area. This service is mainly addressed to passengers but the airlines are also considered as users. Additionally, there is the ability to be provided dynamically information on travel time for the requested departure gate through some standard points that are declared as Internet access points (kiosks) and Information Offices (Information Desks) located in the Main Terminal Building.

The passengers may have access to this service through their smart phone or via computer or a kiosk. Another option is the access via the information desk of an employee. If the passenger uses smart phone, the position will be identified (if (s)he permits it), with the insert of the flight's number in order to be defined the departure gate of the flight and then will display the estimated time at each point in the process. Finally, the map of the route to the departure gate is displayed. In case where a passenger will go to a kiosk, the location of the kiosk will be identified automatically and the estimated time will be calculated and then the user will provide the flight's information. Finally, if (s)he will go to the information desk, the information will be provided through the employee by informed him/her about the code of flight and (s)he then informs the passenger about the estimated time. The employee of the airport will 
Table 5. Time2Gate

\begin{tabular}{|c|c|}
\hline Components & Description \\
\hline Value Proposition & $\begin{array}{l}\text { Dynamic, real-time (real-time) provision of information to passenger for the } \\
\text { required time to go to the boarding gate of his/her flight. }\end{array}$ \\
\hline Customer Segments & $\begin{array}{ll}\text { - } & \text { Registered and non- registered passengers } \\
\text { - } & \text { Registered and non- registered visitors }\end{array}$ \\
\hline Channels & $\begin{array}{l}\text { The users may use this service through: } \\
\text { Smart phones \& laptops users } \\
\text { - Desktops and laptops in kiosks in the Airport } \\
\text { In case of a substantial change in the next years points the user will be } \\
\text { informed with sms for new hours (digital channel) }\end{array}$ \\
\hline Customer Relationships & $\begin{array}{l}\text { Users: businesses } \\
\text { - Service provider -user } \\
\text { - Co-create value between airlines and the Airport (value co- } \\
\text { creation) } \\
\text { Users: airlines, passengers, visitors } \\
\text { - Self - service through automated processes (automation). } \\
\text { - Service provider - user }\end{array}$ \\
\hline Key Resources & $\begin{array}{l}\text { physical resources: e.g. computers, network infrastructure, sensors for } \\
\text { detecting user location and transit time calculation } \\
\text { intellectual resources: e.g. knowledge about the operation of the service, } \\
\text { algorithms / methods of positioning algorithms for calculating the access } \\
\text { time at the gate } \\
\text { Human resources: e.g. staff } \\
\text { Financial resources: revenues from 'Discount Coupons' }\end{array}$ \\
\hline Key Activities & $\begin{array}{l}\text { - } \text { Selection and implementation of algorithms } \\
\text { - Production: design, implementation and launch of the service } \\
\text { - } \text { Maintenance Services } \\
\text { - Production \& maintenance platforms services } \\
\end{array}$ \\
\hline Competitive Advantage & $\begin{array}{l}\text { - Calculation of the gate transit time (combination of Automatic } \\
\text { Identification and assessment of service time in queues and } \\
\text { checkpoints) } \\
\text { - Dynamic Update } \\
\text { - Innovation, Leadership } \\
\text { - Airport's brand name }\end{array}$ \\
\hline Key Partners & $\begin{array}{ll}\text { - } & \text { Business } \\
\text { - } & \text { Airlines } \\
\end{array}$ \\
\hline Revenue Streams & $\begin{array}{l}\text { Charge for business } \\
\text { - Charge for viewing offers through service 'Discount Coupons' } \\
\text { Charge to promote businesses } \\
\text { Charge for users } \\
\text { - One-time charge for sending sms for information in case of a } \\
\text { substantial change in the years following points } \\
\text { One-time charge for using the service to automatically detect the } \\
\text { user's position } \\
\text { One-time charge of mere user of the service (without automatic } \\
\text { user identification) } \\
\text { Charge for airlines } \\
\text { - One-time charge for the rights to use the service } \\
\text { Depending on the times you used the service }\end{array}$ \\
\hline Cost Structure & $\begin{array}{l}\text { - } \quad \text { Purchase of hardware and software } \\
\text { - } \quad \text { Maintenance of hardware and software } \\
\text { - Equipment for positioning systems and calculation queue at } \\
\text { - Checkpoints } \\
\text { Cost of acquisition sms packages }\end{array}$ \\
\hline
\end{tabular}


$\log$ in to the application, and then (s)he will insert the code of the flight and where they are located. Then the time will be estimated and the passenger will be informed about the time that is required in order to go to the gate.

Such a service is used for the first time in the airport area. Furthermore, the user access and use of service will be easy, without requiring specialized knowledge. Finally, the service will be followed by a strong brand name that inspires confidence and trust to people.

The calculation of the gate transition time (a combination of Automatic Identification and assessment of service time in queues and checkpoints) is an innovative service. The dynamic information of the user in case there will be a problem or the sudden existence of a long queue that will increase the estimated time to gate, are innovative aspects and create competitive advantage.

\section{Discussion}

The purpose of our study was to create a platform with services for the passengers, the visitors the firms and their employees of an airport. Through a survey that was conducted with focus groups and questionnaires, four services identified as the most desirable. These services as we described above in detail, are Discount Coupons, Traffic Map, Last Minute Tickets and Time2Gate.

Our research has two important managerial implications. The former is the way that the airport may help the firms to fulfil their customers' needs with a better way, recognising their personal characteristics. Recommender systems become one of the basic parts of the delivery of our services. Being based on this managerial implication, the next objective of our research is the investigation of the way that we may design a more intelligent system; a system which will be able to evaluate the data and propose directly solutions so to the firms as to their customers. The latter, the (technical) way that the recommender systems should be designed in order to achieve higher accuracy to their results.

Acknowledgments. Project Action "COOPERATION 2009" entitled "Common Airport Platform- CAP" code 09SYN-72-799 and sponsored by GSRT. / EYDERTDI - Ministry of Education, Lifelong Learning and Religious Affairs'.

\section{References}

Adamic, L., Adar, E.: How to search a social network. Social Networks 27(3), 187-203 (2005) Bhattacherjee, A.: Individual trust in online firms: Scale development and initial test. Journal of Management Information Systems 19(1), 211-241 (2002)

Chakravarty, A., Liu, Y., Mazumdar, T.: The Differential Effects of Online Word-of-Mouth and Critics' Reviews on Pre-release Movie Evaluation. Journal of Interactive Marketing 24(3), 185-197 (2010)

Cheung, C.M., Lee, M.K.: Understanding consumer trust in Internet shopping: A multidisciplinary approach. Journal of the American Society for Information Science and Technology 57(4), 479-492 (2006)

Corbitt, B.J., Thanasankit, T., Yi, H.: Trust and e-commerce: a study of consumer perceptions. Electronic Commerce Research and Applications 2(3), 203-215 (2003) 
D'Souza, C., et al.: Green decisions: demographics and consumer understanding of environmental labels. International Journal of Consumer Studies 31(4), 371-376 (2007)

Dellarocas, C.: The digitization of word of mouth: Promise and challenges of online feedback mechanisms. Management Science 49(10), 1407-1424 (2003)

Dellarocas, C., Zhang, X., Awad, N.F.: Exploring the value of online product reviews in forecasting sales: The case of motion pictures. Journal of Interactive Marketing 21(4), 23-45 (2007)

Deutsch, M.: Trust and suspicion. Journal of Conflict Resolution 2(4), 265-279 (1958)

Duan, W., Gu, B., Whinston, A.B.: The dynamics of online word-of-mouth and product salesAn empirical investigation of the movie industry. Journal of Retailing 84(2), 233-242 (2008)

Einwiller, S., Geissler, U., Will, M.: Engendering trust in Internet businesses using elements of corporate branding. In: Proceedings of the 2000 Americas Conference on Information Systems (AMCIS 2000), pp. 733-739 (2000)

Friedman, B., Khan, P.H., Howe, D.C.: Trust online. Communications of the ACM 43(12), 3440 (2000)

Galletta, D.F., et al.: Social influence and end-user training. Communications of the ACM 38(7), 70-79 (1995)

Gauri, D.K., Bhatnagar, A., Rao, R.: Role of word of mouth in online store loyalty. Communications of the ACM 51(3), 89-91 (2008)

Gefen, D., Straub, D.W.: Consumer trust in B2C e-Commerce and the importance of social presence: experiments in e-Products and e-Services. Omega 32(6), 407-424 (2004)

Gill, H., et al.: Antecedents Of Trust: Establishing A Boundary Condition For The Relation Between Propensity To Trust And Intention To Trust. Journal of Business and Psychology 19(3), 287-302 (2005)

Grabner-Kräuter, S., Kaluscha, E.A.: Empirical research in on-line trust: a review and critical assessment. International Journal of Human-Computer Studies 58(6), 783-812 (2003a)

Grabner-Kräuter, S., Kaluscha, E.A.: Empirical research in on-line trust: a review and critical assessment. International Journal of Human-Computer Studies 58(6), 783-812 (2003b)

Hann, I.H., et al.: Online information privacy: Measuring the cost-benefit trade-off. In: 23rd International Conference on Information Systems (2002)

Harrison McKnight, D., Choudhury, V., Kacmar, C.: The impact of initial consumer trust on intentions to transact with a web site: a trust building model. The Journal of Strategic Information Systems 11(3-4), 297-323 (2002)

Hu, N., Zhang, J., Pavlou, P.A.: Overcoming the J-shaped distribution of product reviews. Communications of the ACM 52(10), 144 (2009)

Katz, J.E., Rice, R.E.: Social consequences of Internet use: access, involvement, and interaction. MIT Press (2002)

Kim, D.J., Ferrin, D.L., Rao, H.R.: A study of the effect of consumer trust on consumer expectations and satisfaction. In: Proceedings of the 5th International Conference on Electronic Commerce (ICEC 2003), Pittsburgh, Pennsylvania, pp. 310-315 (2003a),

http://portal.acm.org/citation. cfm?id=948046

(accessed December 3, 2010)

Kim, D.J., Ferrin, D.L., Rao, H.R.: A study of the effect of consumer trust on consumer expectations and satisfaction. In: Proceedings of the 5th International Conference on Electronic Commerce (ICEC 2003), Pittsburgh, Pennsylvania, pp. 310-315 (2003b), http://portal.acm.org/citation.cfm?id=948046

(accessed December 4, 2010) 
Kim, D.J., Ferrin, D.L., Rao, H.R.: A trust-based consumer decision-making model in electronic commerce: The role of trust, perceived risk, and their antecedents. Decision Support Systems 44(2), 544-564 (2008)

Kim, D.J., et al.: A multidimensional trust formation model in B-to-C e-commerce: a conceptual framework and content analyses of academia/practitioner perspectives. Decision Support Systems 40(2), 143-165 (2005)

Koufaris, M., Hampton-Sosa, W.: Customer trust online: examining the role of the experience with the Web-site. Department of Statistics and Computer Information Systems Working Paper Series, Zicklin School of Business. Baruch College, New York (2002)

Koufaris, M., Hampton-Sosa, W.: The development of initial trust in an online firm by new customers. Information \& Management 41(3), 377-397 (2004)

Kuan, H.H., Bock, G.W.: Trust transference in brick and click retailers: An investigation of the before-online-visit phase. Information \& Management 44(2), 175-187 (2007)

Lee, J., Lee, J.: Understanding the product information inference process in electronic word-ofmouth: An objectivity-subjectivity dichotomy perspective. Information \& Management 46(5), 302-311 (2009)

Lee, M.K., Turban, E.: A trust model for consumer Internet shopping. International Journal of Electronic Commerce 6(1), 75-91 (2001)

Levitan, L.C., Visser, P.S.: Social network composition and attitude strength: Exploring the dynamics within newly formed social networks. Journal of Experimental Social Psychology 45(5), 1057-1067 (2009)

Liu, C., et al.: Beyond concern-a privacy-trust-behavioral intention model of electronic commerce. Information \& Management 42(2), 289-304 (2005)

McCole, P., Ramsey, E., Williams, J.: Trust considerations on attitudes towards online purchasing: The moderating effect of privacy and security concerns. Journal of Business Research 63(9-10), 1018-1024

Oliver, R.L., Burke, R.R.: Expectation Processes in Satisfaction Formation. Journal of Service Research 1(3), 196-214 (1999); Olson, J.S., Olson, G.M.: i2i trust in e-commerce. Communications of the ACM 43(12), 41-44 (2000)

Ou, C.X., Sia, C.L.: To trust or to distrust, that is the question. Communications of the ACM 52(5), 135 (2009)

Pustejovsky, J.E., Spillane, J.P.: Question-order effects in social network name generators. Social Networks 31(4), 221-229 (2009)

Einwiller, S., Will, M.: The Role of Reputation to Engender Trust in Electronic Markets (2001), http: / / www. communicationsmgt.org/modules/pub/download.php?id= communicationsmgt-11 (accessed December 4, 2010)

Senecal, S., Nantel, J.: The influence of online product recommendations on consumers' online choices. Journal of Retailing 80(2), 159-169 (2004)

Sheppard, B.H., Sherman, D.M.: The Grammars of Trust: A Model and General Implications. The Academy of Management Review 23(3), 422-437 (1998)

Subramani, M.R., Rajagopalan, B.: Knowledge-sharing and influence in online social networks via viral marketing. Communications of the ACM 46(12), 300 (2003)

Teo, T.S., Liu, J.: Consumer trust in e-commerce in the United States, Singapore and China. Omega 35(1), 22-38 (2007)

Walczuch, R., Lundgren, H.: Psychological antecedents of institution-based consumer trust in e-retailing. Information \& Management 42(1), 159-177 (2004) 